\title{
IMPLEMENTASI METODE INQUIRY DISCOVERY UNTUK PEMBENTUKAN KREATIVITAS MAHASISWA DALAM SENI PENYAJIAN MAKANAN
}

\author{
Kokom Komariah \\ Pendidikan Teknik Boga dan Busana \\ Universitas Negeri Yogyakarta \\ E-mail: kokom@uny.ac.id
}

\begin{abstract}
ABSTRAK
Kreativitas dapat dikembangkan melalui berbagai cara, sementara ini implementasi inquiry dan descovery pada praktek seni penyajian makanan belum pernah dikaji. Melalui tulisan ini ingin diketahui apakah penggunaan metode inquiry. Discovery berdampak pada pembentukan kreativitas seni penyajian makanan. Penelitian ini dilakukan melalui penelitian tindakan kelas, metode penelitian dimodifikasi dari Kemmis, setiap siklus dibagi 3 tahap yaitu perencanaan, observasi dan tindakan serta refleksi. Subjek penelitian adalah 39 orang mahasiswa. Pengumpulan data melalui observasi, angket dan wawancara, Analisis data dilakukan secara deskiptif kuantitatif. Hasil penelitian menemukan metode inquiry discovery menunjukkan kreativitas proses sangat baik $(3,44)$ dan kreativitas produk baik $(3,97)$, dan kreativitas individu secara rerata sangat baik $(3,33)$. Dengan demikian proses inquiry dapat membentuk peserta didik untuk berkreasi pada aktivitas seni penyajian makanan, hal ini dapat dibuktikan dengan produk yang dihasilkan lebih bervariasi tidak terpancang pada contoh yang diberikan oleh dosen, dan gambar atau model yang di dapatkan melalui internet.
\end{abstract}

Kata Kunci: kreativitas, metode inquiry discovery, penyajian makanan

\section{PENDAHULUAN}

Tujuan pembangunan nasional adalah membangun manusia seutuhnya, untuk mewujudkan tujuan pembangunan tersebut diperlukan sumber daya manusia yang berkualitas. Guna menghasilkan sumberdaya yang berkualitas diperlukan proses pendidikan yang berkualitas pula.

Guna mendukung proses pendidikan yang berkualitas tidak terlepas dari peran pendidik, karena pendidik mempunyai peran yang sangat vital mulai menentukan tujuan, memilih materi, memilih metode dan strategi serta melakukan evaluasi atau penilaian pada kegiatan pembelajarannya.

Kedudukan metode selain sebagai strategi untuk mencapai tujuan pembelajaran berfungsi sebagai motivasi ekstrinsik untuk memperlancar tercapainya tujuan pembelajaran. Metode menentukan bagaimana guru mengorganisasikan seluruh komponen pembelajaran, termasuk di dalamnya menyampaikan suatu bahan pelajaran.

Mata kuliah seni penyajian makanan sebagai mata kuliah produktif, mempunyai tujuan membekali mahasiswanya tidak hanya keterampilan membuat aneka jenis produk seni tertentu yang dapat diaplikasikan pada makanan, tetapi dituntut mempunyai pengetahuan teori, wawasan dan kreativitas tinggi, yang pada saatnya bisa digunakan dalam kariernya baik sebagai tenaga pendidik ataupun sebagai tenaga profesional di bidang boga.

Seni penyajian makanan, di dasarkan pada konsep seni, yang artinya keahlian membuat karya yang bermutu, atau kesanggupan akal untuk menciptakan sesuatu yang bernilai tinggi. Seni merupakan kebutuhan hidup yang penting, selain 
kebutuhan primerdan kebutuhan sekunder. Manusia memiliki kebutuhan integrative yang berkaitan dengan kebutuhan manusia sebagai makhluk budaya, sehingga mengembangkan seni penyajian makanan merupakan bentuk mengembangkan seni terapan yang berfungsi melatih mahasiswa sehingga dapat melakukan ekspresi diri, menggunakan aspek seni untuk menambah nilai pada makanan.

Sebagai sebuah karya seni, seni penyajian dapat dikaitkan dengan aliran tokoh-tokoh besar seperti Plato yang menjelaskan bahwa seni adalah peniruan terhadap alam, sehingga karya seni merupakan tiruan dari bentuk alam seperti manusia, binatang dan tumbuhan. Aristoteles menambahkan bahwa peniruan terhadap alam itu harus ideal, serba baik, serba sempurna, sedangkan Suzanne K. Langer kesenian adalah penciptaan wujud-wujud yang merupakan symbol dari perasaan manusia.

Berdasarkan beberapa kajian di atas dapat disimpulkan seni penyajian makanan merupakan (1) kegiatan ekspresi rohani/jiwa/gagasan/perasaan manusia; (2) kemahiran/ketrampilan/kelakuan manusia yang luar biasa.; (3) penciptaan yang menghasilkan karya; (4) karya yang memiliki nilai estetis; (5) karya yang memiliki makna simbolik.

Makanan tidak menyangkut hal perut semata, namun wujud makanan yang menarik akan lebih menggugah selera orang yang akan menyantapnya. Oleh sebab itu dalam seni penyajian makanan bentuk dan warna makanan dirancang sedemikian rupa sesuai dengan cita rasa masyarakat.

Perkembangan seni penyajian makanan begitu cepat, berubah dari waktu ke waktu. Keadaan ini menuntut para pendidik mempunya strategi atau cara tertentu agar materi ajar tidak selalu ketinggalan. Dalam hal ini kemampuan mahasiswa sebagai peserta didik dewasa bisa dioptimalkan, dimana mereka tidak sekadar diberi atau diajari materi melalui proses peniruan, tetapi sampai bisa menghasilkan produk tertentu dan menghasilkan produk sesuai dengan kreasinya.
Kreativitas didefinisikan secara berbedabeda. Sedemikian banyak definisi kreatifitas. [2], mengelompokkan kreativitas dalam dimensi person, proses, produk, dan press. Kreativitas sebagai person menunjuk pada kemampuan yang menjadi karateristik orangorang kreatif. Kreativitas sebagai proses adalah sebuah proses yang memanifestasikan dirinya dalam suatu kondisi dan fleksibel seperti pemikiran aslinya. Kreativitas sebagai produk adalah kemampuan untuk membawa sesuatu yang baru pada suatu keberadaan. Kreativitas dapat ditunjukkan dengan kualitas produk atau respon daripada penilai yang menunjukkan kekreativan tersebut.

Menurut [3] menjelaskan bahwa kreativitas adalah kemampuan untuk membuat kombinasi-kombinasi baru atau melihat hubungan-hubungan baru antara unsur, data, variabel, yang sudah ada sebelumnya, atau kreativitas adalah kemampuan seseorang untuk melahirkan sesuatu yang baru, baik berupa gagasan maupun karya nyata.

Menurut [9], karya kreatif membutuhkan kemampuan menerapkan dan menyeimbangkan tiga kemampuan, yaitu (1) Synthetic ability is what we typicalally think of as creativity, (2) Analytic ability is typicalally considerared to be critical thinking ability. (3) Practical ability is the ability to translate theory into practice and abstract ideas into practical accomplishment. Ketiga hal tersebut menunjukkan bahwa orang yang mempunyai kemampuan mensintesis, analitik dan evaluasi biasanya kita anggap sebagai orang yang kreatif, kemampuan tersebut dapat menghasilkan ide-ide baru dan menarik, selanjutnya dibutuhkan juga kemampuan untuk menterjemahkan teori ke dalam praktek, atau menterjemahkan ide abstrak menjadi hal-hal yang praktis.

Selanjutnya dalam konteks kreativitas keilmuan, [2] mengartikan ilmu sebagai system berfikir yang melibatkan serangkaian aktivitas kreatif dan imajinatif ilmuwan dalam upayanya mencari kebenaran. Mengacu pada profesi guru sebagai soft profession, maka guru dituntut untuk kreatif. Prestasi kreatif itu sendiri di 
bidang keilmuan menuntut tiga prasyarat yaitu (1) kemampuan intelektual yang memadai, (2) motivasi dan komitmen untuk mencapai keunggulan, dan (3) penguasaan terhadap bidang ilmu yang ditekuni. Ketiga aspek tersebut secara interaktif membentuk prilaku kreatif yang kemudian menghasilkakan produk kreatif.

Berdasarkan hal tersebut, dapat disimpulkan untuk menjadi guru yang kreatif harus mempunyai kemampuan intelektual yang ditunjukkan oleh prestasi akademik yang relative menonjol, mempunyai motivasi yang kuat untuk meraih prestasi dan mencapai keunggulan, serta penguasaan yang memadai terhadap bidang yang ditekuninya.

Selanjutnya digambarkan oleh [2] faktorfaktor yang membentuk prestasi kreatif yaitu kecakapan, motivasi dan keterampilan. Ketiga faktor tersebut akan berinteraksi dan menghasilkan perilaku kreatif. Lebih jelas dapat dijelaskan dalam gambar berikut:

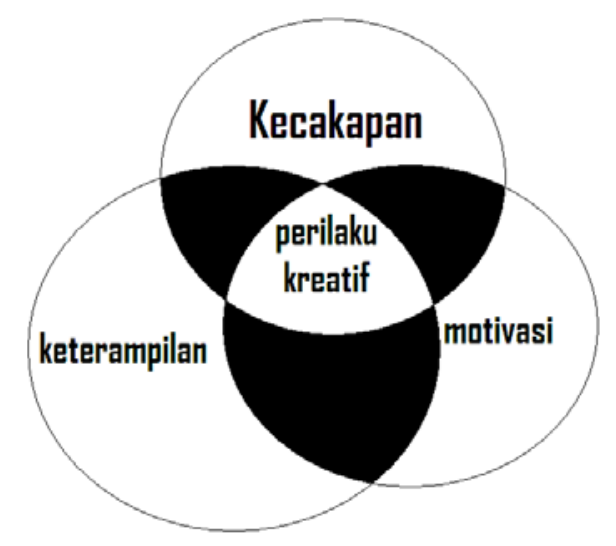

Gambar 1 : Faktor-faktor yang membentuk prestasi kreatif [2]

Berdasarkan hal di atas, pembentukan kreativitas sangat penting, karena kreativitas adalah kemampuan yang dimiliki oleh seseorang untuk memahami keadaan/dunia, dalam menginterprestasikan pengalaman dan memecahkan masalah dengan cara yang baru dan orisinal, sehingga pada saatnya mahasiswa dapat menjadi pribadi yang mandiri dan kreatif.

Penerapan seni dalam penyajian makanan, membutuhkan kreativitas yang tinggi, artinya seorang yang ingin berprofesi di dalam penyajian makanan sangat dituntut untuk selalu belajar terus menerus, berkreasi secara terus menerus, karena sebuah produk yang akan dihasilkan, pada saatnya akan mengalami kejenuhan bahkan kematian. Untuk mengantisipasi hal tersebut maka perlu dipilih metode yang tepat untuk mengatasinya. Salah satu metode yang diasumsikan cocok untuk mengatasi kesenjangan ini adalah metode inquiry-discovery

Inti dari metode inquiry-discovery adalah pencarian makna belajar.. Individu yang belajar dimotivasi untuk meningkatkan kompleksitas struktur intelektualnya agar dapat memproses suatu informasi dan mencari secara kontinyu untuk membuat suatu perencanaan sehingga lebih bermakna. Selanjutnya [1] menjelaskan bahwa metode inquiri berkonsentrasi pada upaya menilai dan mengamati proses pemberian perhatian pada suatu obyek, berinteraksi dengan apa yang dirangsang oleh orang lain baik secara langsung atau melalui tulisannya, merefleksi dan reorganisasi konsep dan sikap seperti yang ditunjukkan dalam proses menarik kesimpulan, mengidentifikasi, pencarian baru, mengambil tindakan, dan mengubahnya agar menghasilkan yang lebih baik.

Menurut [5], bahwa belajar penemuan (discovery learning) dapat juga disebut proses pengalaman. Langkah-langkah proses pengalaman ini adalah (1) Tindakan dalam kondisi tertentu. Siswa melakukan tindakan dan mengamati pengaruh-pengaruhnya.

Pemahaman kasus tertentu. Apabila keadaan yang sama muncul kembali, maka ia dapat mengantisipasi pengaruh yang bakal terjadi dan konsekwensi-konsekwensinya; (3) Generalisasi. Siswa membuat kesimpulan atas prinsip-prinsip umum berdasarkan pemahaman terhadap kondisi tertentu, dan (4) Tindakan dalam suasana baru. Siswa menerapkan prinsip dan mengantisipasi pengaruhnya.

Berdasarkan hal tersebut salah satu hal yang perlu dilakukan adalah mengimpementasikan metode inquiry dan discovery dalam proses belajar mengajar, agar 
dihasilkan calon-calon guru yang kompetitif, dan pada saatnya lulusan memiliki etos kerja mandiri, percaya diri, dan kreatif.

\section{METODE}

Jenis penelitian ini termasuk penelitian tindakan kelas, metode penelitian dimodifikasi dari Kemmis, setiap siklus dibagi 3 tahap yaitu perencanaan, observasi dan tindakan yang dapat digambarkan sebagai berikut:

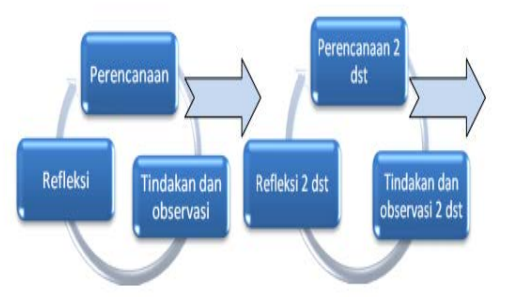

Gambar 2. Modifikasi Model Penelitian Tindakan dari Kemmis

Penelitian dilakukan di Program Studi Pendidikan Teknik Boga . Subjek penelitian ini adalah siswa 39 orang mahasiswa. Objek penelitian adalah penerapan metode inquiry dan discovery pada proses belajar mengajar mata kuliah seni penyajian makanan tahun ajaran 2013-2014 Diharapkan dengan menerapkan metode inquiry maka kreativitas mahasiswa akan meningkat.

Tabel 1.Pelaksanaan Siklus I untuk Pelaksanaan Pembelajaran Seni Penyajian Makanan

\begin{tabular}{|c|c|c|}
\hline No & Langkah & Kegiatan \\
\hline 1. & Persiapan & $\begin{array}{l}\text { Kegiatan yang dilakukan Dosen } \\
\text { a) Mahasiswa dibagi kelompok kerja. } \\
\text { b) Mahasiswa diberi masalah sesuai dengan topik-topik untuk digali, ditelaah } \\
\text { dan dikembangkan }\end{array}$ \\
\hline 2. & Pelaksanaan & $\begin{array}{l}\text { Kegiatan yang dilakukan Mahasiswa } \\
\text { a) Mahasiswa melakukan pengumpulan data untuk dikaji, sifat khusus dari } \\
\text { objek yang dipelajari. } \\
\text { b) Mahasiswa mengumpulkan data, mengumpulkan materi pada topik-topik } \\
\text { yang relevan. } \\
\text { c) Merumuskan penemuan inquiry, sehingga diperoleh penjelasan, pernyataan, } \\
\text { atau prinsip yang lebih formal, dalam bentuk laporan. } \\
\text { d) Mengkomunikasikan proses inquiry-descovery, di depan kelas. }\end{array}$ \\
\hline 3. & $\begin{array}{l}\text { Observasi dan } \\
\text { Refleksi }\end{array}$ & $\begin{array}{l}\text { Kegiatan yang dilakukan Dosen } \\
\text { a) Mencatat semua peristiwa yang terjadi selama mahasiswa melakukan proses } \\
\text { inquiry. } \\
\text { b) Mencatat, mengidentifikasi, mengklasifikasi proses refleksi }\end{array}$ \\
\hline
\end{tabular}

Kegiatan persiapan pertama kali dilakukan pembagian kelompok kerja oleh dosen. Tujuan pembagian kelompok ini agar
Data diperoleh secara kualitatif dan kuantitatif. Data kualitatif diperoleh berdasarkan hasil refleksi mahasiswa yang dicatat, diidentifikasi, dan dikelompokkan sehingga data tersebut menjadi informasi yang bermakna. Data kuantitatif diperoleh berdasarkan skala model likert untuk mengukur kreatifitas mahasiswa berdasarkan kisi-kisi yang dikembangkan oleh [2] yang meliputi kualitas person, proses dan hasil. Data kuanlitatif dianalisis dengan persentase, dicari rata-rata, interval dan kecenderungannya.

\section{HASIL DAN PEMBAHASAN}

1. Implementasi Metode Inquiry dan discovery

Penelitian dengan treatment penggunaan meted inquiry dan discovery dilaksanakan dalam 2 (dua) siklus yang dipaparkan sebagai berikut:

a. Tindakan Siklus 1

Pada tindakan siklus 1 pelaksanaan pembelajaran, sesuai dengan skenario siklus ini terintegrasi dalam kegiatan tatap muka dalam proses pembelajaran pertemuan pertama dan kedua. Langkah-langkah pelaksanaan siklus pertama dapat disajikan sebagai berikut: 
diberi masalah sesuai dengan topik-topik untuk digali, ditelaah dan dikembangkan. Topik-topik yang digali dan dikembangkan adalah sebagai berikut: garnish sayuran, platting, food models, fruit carving, samir, menghias gelas, merangkai bunga dan buah membuat doos hias. Penggalian topik, dimulai dari manfaat, jenis bahan, macam-macam desain yang dapat dikembangkan, alat kerja yang dibutuhkan, karakteristik bahan yang dibutuhkan, dan prosedur kerja.

Pelaksanaan kegiatan inquiry dilakukan mahasiswa dengan pengumpulan data untuk dikaji, sifat khusus dari objek yang dipelajari. Materi yang dominan saat ini didapat melalui internet, youtobe, majalah, melakukan survey ke lapangan. Beberapa mahasiswa sangat tertarik dengan tugas yang diberikan. Mereka mencoba mempraktekan apa yang mereka ketahuinya, sehingga saat proses Tabel 2. Pelaksanaan Siklus II untuk Pelaksanaan Pembelajaran

\begin{tabular}{|c|c|c|}
\hline No & Langkah & Kegiatan \\
\hline 1. & Persiapan & $\begin{array}{l}\text { Kegiatan yang dilakukan Dosen } \\
\text { a) Membagi kelompok kerja. } \\
\text { b) Dosen membuat instrument untuk refleksi dan penilaian kreativitas } \\
\text { b) Mahasiswa diberi tugas untuk mewujudkan produk, sesuai dengan proses } \\
\text { inquiry. }\end{array}$ \\
\hline 2. & Pelaksanaan & $\begin{array}{l}\text { Kegiatan yang dilakukan Mahasiswa } \\
\text { a) Mahasiswa melakukan proses perancangan produk. } \\
\text { b) Mahasiswa menyiapkan alat, bahan utama dan bahan pembantu untuk } \\
\text { mewujudkan produk. } \\
\text { c) Mahasiswa mewujudkan produk sesuai dengan proses inquiry. }\end{array}$ \\
\hline 3. & $\begin{array}{l}\text { Observasi dan } \\
\text { Refleksi }\end{array}$ & $\begin{array}{l}\text { Kegiatan yang dilakukan Dosen } \\
\text { a) Mencatat semua peristiwa yang terjadi selama mahasiswa mewujudkan produk } \\
\text { b) Merekam proses kreativitas mahasiswa berdasarkan kreatifitas person, proses dan } \\
\text { hasil. }\end{array}$ \\
\hline
\end{tabular}

Tahap persiapan diarahkan untuk

mewujudkan produk sebagai proses inquiry. Penerapannya mahasiswa membuat rancangan produk, menyiapkan alat, bahan utama dan bahan pembantu untuk mewujudkan produk sesuai dengan proses inquiry.

Berdasarkan hasil penerapan siklus 1 dan siklus II diperoleh gambaran , bahwa mahasiswa belajar mealui proses inquirydiscovery dengan menerapkan tahapan-tahapan kegiatan seperti tergambar dalam kegiatan berikut: pengkomunikasian topik yang mereka pelajari mereka sudah dapat memperagakan produknya di depan kelas.

Materi seni penyajian sebagai ilmu yang pragmatis berkembang sangat pesat sehingga proses inquiry sangat membantu. Setelah materi terkumpul, selanjutnya mahasiswa melalui proses pembimbingan dan komunikasi dapat melakukan memberikan penjelasan, pernyataan, konsep atau prinsip yang lebih formal, dalam bentuk laporan. Pelaksanaan siklus pertama diakhiri dengan presentasi dan diskusi sebagai pertanggungjawaban dari proses inquiry dan discovery.

\section{b. Tindakan Siklus II}

Pada tindakan siklus II pelaksanaan pembelajaran, sesuai dengan skenario dilaksanakan dalam 5 pertemuan. 


\section{Dampak Penggunaan Metode Inquiry Discovery pada Kreativitas Mahasiswa}

Mengacu pada kreativitas yang dikemukakan oleh [2] membagi menjadi 3 (tiga), yaitu kreativitas person, kreatvitas proses, dan kreativitas produk. Penilaian kreativitas sebagai proses inquiry melalui tindakan kelas ini dapat disajikan sebagai berikut:

Tabel 3. Kreativitas Person (individu) dalam Seni Penyajian Makanan

\begin{tabular}{clcccc}
\hline \multicolumn{1}{c}{ Kreativitas Person } & Skor & Rerata & Rangk & Kriteria \\
\hline 1. & $\begin{array}{l}\text { Kemampuan untuk membuat kombinasi- } \\
\text { kombinasi baru. }\end{array}$ & $\mathbf{1 3 2}$ & $\mathbf{3 , 3 8}$ & 2 & Baik \\
2. & $\begin{array}{l}\text { Kemampuan melihat hubungan-hubungan baru } \\
\text { berdasarkan unsure yang sudah ada } \\
\text { sebelumnya. }\end{array}$ & 124 & 3,18 & 3 & Baik \\
3. & $\begin{array}{l}\text { Kemampuan untuk menyajikan sesuatu yang } \\
\text { baru . }\end{array}$ & 134 & 3,43 & 1 & $\begin{array}{l}\text { Sangat } \\
\text { Baik }\end{array}$ \\
\hline & Rerata & 130 & 3,33 & & $\begin{array}{l}\text { Sangat } \\
\text { Baik }\end{array}$ \\
\hline
\end{tabular}

Melalui proses inquiry, dapat diamati bahwa kreativitas proses seluruh indikator dalam kategori sangat baik. Mahasiswa mampu berdaptasi dengan bahan, alat, dan kondisi yang tersedia $(3,48)$. , Berusaha untuk mencapai produk secara optimal $(3,43)$ dan mengkodisikan dirinya untuk Tabel 5. Kreativitas Produk dalam Seni Penyajian Makan

\begin{tabular}{clcccc}
\hline No & \multicolumn{1}{c}{ Kreativitas Produk } & \multicolumn{2}{c}{ Skor } & Rank & Kriteria \\
\hline 1. & $\begin{array}{l}\text { Kebaharuan produk yang } \\
\text { ditampilkan }\end{array}$ & 121 & 3,10 & 1 & Baik \\
2. & $\begin{array}{l}\text { Kualitas produk (kerapihan, } \\
\text { keindahan, proporsi, komposisi) }\end{array}$ & 119 & 3,05 & 2 & Baik \\
\hline Rerata & 120 & 3,075 & Baik
\end{tabular}

Ada 2 (dua) indikator yang dihasilkan dari kreativitas produk, yang meliputi kebaharuan produk dan kualitas produk. Hasil penelitian menunjukkan kedua indikator tersebut menunjukkan kriteria baik, dengan rerata skor 3,075. Walaupun skor rerata mencapai produk yang optimal $(3,41)$. Keberhasilan dalam kreativitas proses tidak terlepas dari peranan metode inquiry yang secara konsep memiliki kemampuan untuk memperbaiki dan memperluas penguasaan keterampilan proses dalam memperoleh kognitif para peserta didik.
Tabel6. Rekapitulasi Kreativitas Mahasiswa dalam Seni Penyajian Makanan

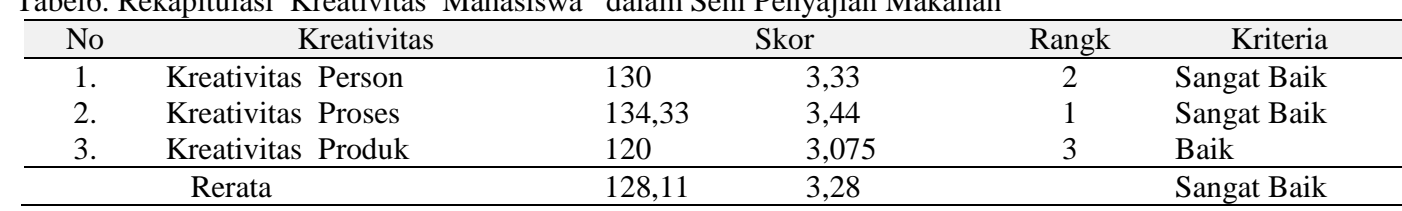

Secara keseluruhan kreativitas

mahasiswa menunjukkan kriteria sangat baik. Apabila dikaitkan dengan prinsip metode inquiry yang menekankan pada keaktifan peserta didik, dan guru hanya berperan sebagai fasilitator, motivator dalam proses pembelajaran , sehingga tidak menjadikan guru sebagai satu-satunya sumber. Dengan demikian kreativitas produk tidak setinggi kreativitas person dan proses namun kreativitas produk sesungguhnya merupakan tujuan iringan dari metode inquiry bahwa peserta didik, yaitu dapat lebih mengembangkan daya kretivitas siswa [5].

kreativitas yang tinggi disebabkan karena pembelajaran ini bersifat student centre.

\section{SIMPULAN}

Berdasarkan hasil penelitian yang dilaksanakan, maka dapat ditarik simpulan sebagai berikut: 
1. Implementasi metode inquiry dan discovery, dilaksanakan dalam 2 (dua) siklus, yang masing-masing terdiri dari perencanaan, pelaksanaan, observasi dan refleksi. Temuan dari silkus tersebut memantapkan bahwa tahapan inquiry dan discovery yang dilakukan oleh mahasiswa sebagai peserta didik meliputi 7 (tujuh) tahap yaitu mengkaji tugas-tugas yang diberikan, melakukan pengumpulan materi untuk dikaji dan didiskusikan, melakukan pemilahan topik seni penyajian makanan, menemukan inti permasalahan dan pembuatan produk seni penyajian makanan, menemukan prinsip prinsip untuk pembuatan produk seni penyajian makanan, mempresentasikan tugas hasil proses inquiry di depan kelas, mewujudkan produk yang dikaji sebagai proses inquiry.

2. Dampak Penggunaan Metode inquiry discovery pada meningkatnya kreativitas mahasiswa pada masing-masing topik seni penyajian makanan produk yang dihasilkan lebih bervariasi pada setiap produknya, tidak terpancang pada contoh yang diberikan oleh dosen dan mahasiswa lebih siap dengan rancangan baru. Hasil proses inquiry menunjukkan kreativitas person menunjukkan rerata sangat baik, kualitas proses sangat baik, dan kualitas produk baik

\section{SARAN}

1. Kompetensi seni penyajian makanan merupakan salah satu kompetensi yang harus dikuasai oleh mahasiswa yang menekankan pentingnya keterampilan dan kreativitas. Penggunaan metode inquiry dan discovery dapat membantu mengatasi kesenjangan yang ada akarena pesatnya perkembangan teknologi dan informasi di bidang jasa boga, oleh karena itu metode ini sangat tepat digunakan sebagai salah satu metoda dalam seni penyajian makanan. Mahasiswa terlatih untuk melakukan penemuan sehingga pada saatnya dapat digunakan untuk memenuhi kebutuhan dirinya dan masyarakatnya.

2. Penggunaan metode inquiry dan discovery dapat digunakan secara mendalam dalam upaya upaya menggali prinsip, konsep dan teori lebih jauh khususnya ilmu-ilmu pragmatis yang berkembang di lapangan.

3. Produk-produk yang dihasilkan oleh mahasiswa dapat digunakan sebagai bahan pengayaan materi seni penyajian dan pengembangan agar tidak terjadi stagnasi pada produk. Pada mata kuliah seni penyajian makanan, dengan penggalian materi yang terus menerus, maka proses belajar mengajar yang sesungguhnya terjadi, dan secara langsung maupun tidak langsung materi pembelajaran akan selalu terbaharukan.

\section{REFERENCES}

[1] Calhoun, C.C., Finch, A.V. (1982) . Vocational Education: Concepts and Operations ( $2^{\text {nd }}$ ed.). Belmont, California: Wadworth Publishing Company.

[2] Dedi Supriadi. (2002) . Kreativitas, Kebudayaan, dan Perkembangan Iptek. Bandung : Alfabeta

[3] Finch, C.R., dan Crunkilton, J.R. (1984). Curriculum Development in Vocational and Technical Education: Planning, Content and Implementation. Boston: Allyn and Bacon, Inc.

[4] http://dasar-teori. blogspot.com /2011/08/pengertian-metodepembelajaran 01.html, diakses Februari 2014.

[5] Oemar Hamalik . (2001). Proses Belajar Mengajar. Jakarta: PT Bumi Aksara:

[6] Oemar Hamalik. (2009). Strategi Belajar Mengajar. Bandung: Sinar Baru Algensindo

[7] Purwadarminta. (2007). Kamus Besar Bahasa Indonesia. (edisi ketiga). Jakarta: Pusat Bahasa Departemen Pendidikan Nasional 
[8] Sismono La Ode, dkk . (2006). Di Belantara Pendidikan Bermoral. Biografi Pemikiran dan Kepemimpinan Prof. Suyanto, Ph.D. Yogyakarta: UNY Press.
[9] Stemberg J.R \& Williams, M.W (1996:3) How to Develo Student Creativity. Alexandria Virginia: Assosiation for Supervition and Curiculum Development 